\title{
Digestibilidade e Nutrientes Digestíveis Totais de Camas de Frango para Ruminantes ${ }^{1}$
}

\section{Arnaud Azevêdo Alves ${ }^{2}$, Abelardo Ribeiro de Azevedo ${ }^{3}$, Francisco Militão de Sousa ${ }^{3}$, Antonio Luciano Tavares Ciríaco ${ }^{4}$}

\begin{abstract}
RESUMO - Este experimento foi realizado para avaliar a digestibilidade in vivo e os nutrientes digestíveis totais (NDT) de camas de frango formadas por diferentes materiais absorventes. Vinte carneiros castrados da raça Morada Nova foram alojados em gaiolas metabólicas e arreados com sacolas para coleta total de fezes. O delineamento experimental foi o de blocos ao acaso, com quatro tratamentos e cinco repetições. Os tratamentos consistiram de fontes alternativas de cama de frango: A - raspa de madeira, B - capimelefante Napier, C - sabugo de milho com palha e D - parte aérea da mandioca. A digestibilidade dos nutrientes e o valor energético com base no NDT, das camas de frango de sabugo de milho com palha e de capim-elefante, apresentaram valor nutritivo melhor que o da cama de frango de raspa de madeira para ruminantes.
\end{abstract}

Palavras-chave: cama de frango, digestibilidade, NDT, ovino

\section{Digestibility and Total Digestible Nutrients of Poultry Litters for Ruminants}

\begin{abstract}
This experiment was conducted to evaluate the digestibility and total digestive nutrients (TDN) of poultry litter made from different types of absorbent materials. Twenty castrated sheeps of Morada Nova breed were allotted to metabolic cages and fitted with bag device for total feces collection. The experimental design was a randomized block with four treatments and five replicates. The treatments consisted in alternatives sources of poultry litter: A - wood shavings, B - elephant "Napier" grass, C - corncob with husks and D - aerial part of cassava. The nutrient digestibility and the energetic value as TDN base, of the corncob with husk and elephant "Napier" grass poultry litter showed better nutritive value than the wood shaving poultry litter for ruminants.
\end{abstract}

Key Words: poultry litter, digestibility, TDN, sheep

\section{Introdução}

As proteínas são de fundamental importância na alimentação dos ruminantes, pois apresentam-se intimamente relacionadas com os processos vitais das células orgânicas. No entanto, os ingredientes protéicos são normalmente caros e, portanto, algumas alternativas de menor custo têm sido estudadas - como, por exemplo, a cama de frango, que se constitui em boa fonte de nitrogênio e de minerais (SAMPAIO et al., 1995).

Segundo EL-SABBAN et al. (1970), a utilização de subprodutos da avicultura como alimento é decorrente de disponibilidade, economicidade, valor nutritivo, redução da poluição ambiental e limitação de áreas para produção animal. Além disso, a reciclagem de dejetos para alimentação fundamenta-se na diferente capacidade de digestão de um mesmo alimento por diferentes espécies animais.

Um dos principais fatores que influenciam o valor nutritivo da cama de frango é o material absorvente, o qual está relacionado diretamente com a constituição fibrosa e, principalmente, o grau de lignificação. SOBREIRA et al. (1996) determinaram a composição da fração fibrosa das camas de frango de raspa de madeira, capim-elefante "Napier", sabugo com palha e parte aérea da mandioca, obtendo os respectivos teores: FDA, 48,78; 37,91; 31,55; e 35,81\%, FDN, 72,02; 68,04; 67,42; e 62,35\%, celulose, 31,47; 31,$44 ; 21,25$; e $25,59 \%$, hemicelulose, 23,$42 ; 30,13$; 35,87 ; e 27,59\% e lignina, 14,$78 ; 6,44 ; 4,01$; e $10,36 \%$.

A digestibilidade é um dos principais métodos biológicos para se determinar o valor nutritivo dos alimentos. AZEVEDO et al. (1999) obtiveram para camas de frango de sabugo com palha, capim-elefante "Napier", parte aérea da mandioca e raspa de madeira, em ovinos, as respectivas digestibilidades in vivo: FDA, 65,40; 59,99; 48,25; e 30,79\%, FDN, 69,71; 59,$27 ; 52,64 ;$ e $40,38 \%$, celulose, 69,$57 ; 65,57 ; 56,62$; e $34,91 \%$ e hemicelulose, 72,$10 ; 65,88 ; 65,34 ;$ e $61,62 \%$.

Os objetivos desta pesquisa foram avaliar a

\footnotetext{
1 Parte da dissertação de Mestrado do primeiro autor, apresentada ao DZ/CCA/UFC.

2 Professor do DZO/CCA/UFPI.

3 Professor do DZ/CCA/UFC.

${ }^{4}$ Professor da FAVET/UECE.
} 
digestibilidade in vivo em ovinos e calcular o teor de NDT de camas de frango formadas por raspa de madeira, capim elefante, sabugo com palha e parte aérea da mandioca.

\section{Material e Métodos}

Esta pesquisa foi desenvolvida no Departamento de Zootecnia do Centro de Ciências Agrárias da Universidade Federal do Ceará, em Fortaleza, CE.

O experimento seguiu o delineamento em blocos ao acaso, com quatro tratamentos, A - raspa de madeira, B - capim elefante Napier, C - sabugo com palha e D - parte aérea da mandioca, e cinco blocos.

O capim-elefante, que se apresentava em início de floração, e a parte aérea da mandioca foram desintegrados em máquina forrageira a partículas com cerca de $2,0 \mathrm{~cm}$ e desidratados ao sol. Para uniformização do material absorvente, a raspa de madeira, proveniente de diferentes espécies silvícolas, e o sabugo com palha também foram desintegrados a partículas com cerca de $2,0 \mathrm{~cm}$.

As camas de frango foram obtidas de criação de frangos de corte da linhagem "Hubbard", não-sexados, em uma densidade de 10 aves $/ \mathrm{m}^{2}$, alojados em galpão cimentado, onde foram distribuídos os materiais, na proporção de $1,0 \mathrm{~kg} / \mathrm{ave}$, e submetidos a manejo recomendado por ENGLERT (1998) durante os 49 dias de criação. A formulação e o fornecimento de rações para as aves seguiram metodologia adotada por GARCIA et al. (1997).

A partir dos 28 dias de produção, as camas de frango foram revolvidas semanalmente e, quando da retirada das aves, foram estocadas por 14 dias, em montes de aproximadamente $320 \mathrm{~kg}$, em ambiente coberto, quando se iniciou o ensaio de digestibilidade in vivo. A estocagem da cama de frango e a retirada de aves mortas foram medidas adotadas visando evitar possível contaminação das camas por esporos de Clostrídios e permitir decréscimo no número de microrganismos, segundo recomendações de SCHOCKEN-ITURRINO et al. (1992) e POLAQUINI et al. (1997).

Foram utilizados 20 ovinos da raça Morada Nova, com idade média de 18 meses e peso vivo de $23 \pm 1,7 \mathrm{~kg}$, castrados e caudectomizados, em bom estado sanitário e nutricional, mantidos em gaiolas de metabolismo e arreados com sacolas de napa para coleta de fezes.

A fase de coleta teve duração de sete dias, sendo precedida por um período de adaptação de catorze dias. Durante os sete primeiros dias de adaptação, os ovinos receberam cama de frango em quantidades crescentes, em mistura com concentrado. A partir do oitavo dia e durante a fase de coleta, as camas de frango constituíram alimento exclusivo, fornecido em duas refeições, às 8 e $16 \mathrm{~h}$, correspondendo ao consumo do dia anterior acrescido de $20 \%$. Foram fornecidas água e mistura mineral ad libitum.

Durante a fase de coleta, a intervalos de 24 horas, foram registrados os pesos do alimento fornecido, das sobras e das fezes. Foram obtidas amostras diárias do alimento fornecido e sobras ( $15 \%$ do total) e das fezes ( $5 \%$ do total). As amostras de alimento e sobras foram conservadas em lugar seco e as de fezes, em freezer $\left(-5\right.$ a $\left.-10^{\circ} \mathrm{C}\right)$.

As amostras de fezes foram descongeladas e homogeneizadas por animal, constituindo amostras compostas, pré-secas em estufa com circulação forçada de ar a $55^{\circ} \mathrm{C}$ e trituradas em moinho tipo "Wiley" com peneira de malha 1,0 mm de diâmetro, obtendose sub-amostras de $300 \mathrm{~g}$.

Os teores de matéria seca, matéria mineral, matéria orgânica, proteína bruta, extrato etéreo, fibra em detergente neutro, extrato não-nitrogenado, energia bruta e lignina das amostras foram obtidos segundo técnica descrita por SILVA (1981).

Os nutrientes digestíveis totais (NDT) foram obtidos utilizando-se a fórmula descrita por ENSMINGER et al. (1990).

As variáveis que apresentaram significância em nível de 5\% de probabilidade na análise da variância foram comparadas pelo teste Tukey, proposto por SNEDECOR e COCHRAN (1980).

\section{Resultados e Discussão}

A análise da variância dos dados revelou que os tratamentos influenciaram $(\mathrm{P}<0,01)$ a digestibilidade da matéria seca (DMS), matéria orgânica (DMO), proteína bruta (DPB), fibra em detergente neutro (FDN) e energia bruta (DEB) e o NDT, porém não influiu na digestibilidade do extrato etéreo (DEE) e do extrato não-nitrogenado (DENN).

Os resultados da composição químicobromatológica estão apresentados na Tabela 1 e da digestibilidade aparente dos nutrientes e a concentração de NDT, na Tabela 2.

Os teores de matéria seca das camas de raspa de madeira e de capim-elefante apresentaram-se superiores e os teores de proteína bruta, inferiores aos valores obtidos por ANGELO et al. (1997), os quais trabalharam com a proporção de $4,3 \mathrm{~kg}$ de cama $/ \mathrm{m}^{2}$ 
Rev. bras. zootec.

Tabela 1 - Composição químico-bromatológica das camas de frango (\% MS)

Table 1 - Chemical composition of the broiler litter (\% DM)

\begin{tabular}{|c|c|c|c|c|}
\hline \multirow[t]{2}{*}{$\begin{array}{l}\text { Composição } \\
\text { Composition }\end{array}$} & \multicolumn{4}{|c|}{$\begin{array}{c}\text { Cama de frango } \\
\text { Broilerlitter }\end{array}$} \\
\hline & $\begin{array}{l}\text { Raspa de madeira } \\
\text { Wood shavings }\end{array}$ & $\begin{array}{c}\text { Capim-elefante } \\
\text { Napier } \\
\text { Elephant "Napier"'grass }\end{array}$ & $\begin{array}{l}\text { Sabugo com palha } \\
\text { Corncob with straw }\end{array}$ & $\begin{array}{c}\text { Parte aérea } \\
\text { da mandioca } \\
\text { Aerial part of cassava }\end{array}$ \\
\hline $\begin{array}{l}\text { Matéria seca } \\
\text { Dry matter }\end{array}$ & 84,94 & 82,06 & 81,26 & 83,45 \\
\hline $\begin{array}{l}\text { Matéria orgânica } \\
\text { Organic matter }\end{array}$ & 90,99 & 87,20 & 89,53 & 88,12 \\
\hline $\begin{array}{l}\text { Proteína bruta } \\
\text { Crude protein }\end{array}$ & 10,29 & 10,50 & 10,55 & 13,23 \\
\hline $\begin{array}{l}\text { Extrato etéreo } \\
\text { Ether extract }\end{array}$ & 1,07 & 2,38 & 1,30 & 1,56 \\
\hline $\begin{array}{l}\text { Fibra detergente neutro } \\
\text { Neutral detergent fiber }\end{array}$ & 72,17 & 63,69 & 69,28 & 61,60 \\
\hline $\begin{array}{l}\text { Extrato não-nitrogenado } \\
\text { Nitrogen-free extract }\end{array}$ & 39,41 & 44,31 & 49,49 & 44,88 \\
\hline $\begin{array}{l}\text { Lignina } \\
\text { Lignin }\end{array}$ & 13,50 & 5,91 & 6,02 & 9,99 \\
\hline $\begin{array}{l}\text { Energia }(\mathrm{kcal} / \mathrm{kg} \mathrm{MS}) \\
\text { Energy }(\mathrm{kcal} / \mathrm{kg} D M)\end{array}$ & 4046,00 & 3824,00 & 3850,00 & 3816,00 \\
\hline
\end{tabular}

Tabela 2 - Digestibilidade in vivo e nutrientes digestíveis totais (NDT) dos princípios nutritivos das camas de frango em função dos materiais absorventes alternativos

Table 2 - In vivo digestibility and total digestible nutrients (TDN) of nutritive principles of the different types of broiler litter Coeficiente de Cama de frango

digestibilidade $(\%)$ Broiler litter

Coefficient

of digestibility

$(\%)$

\begin{tabular}{ccccc}
$\begin{array}{c}\text { Raspa de madeira } \\
\text { Wood shavings }\end{array}$ & $\begin{array}{c}\text { Capim-elefante } \\
\text { Elephant grass }\end{array}$ & $\begin{array}{c}\text { Sabugo com palha } \\
\text { Corncob with straw }\end{array}$ & $\begin{array}{c}\text { Parte aérea } \\
\text { da mandioca } \\
\text { Aerial part of cassava }\end{array}$ & $\begin{array}{c}\mathrm{CV} \\
(\%)\end{array}$ \\
\hline $42,68^{\mathrm{b}^{*}}$ & $55,62^{\mathrm{a}}$ & $58,11^{\mathrm{a}}$ & $52,02^{\mathrm{a}}$ & 6,74
\end{tabular}

Matéria seca

55,62

$40,77^{\mathrm{b}}$

$54,45^{\mathrm{a}}$

$55,74^{\mathrm{a}}$

$48,25^{\mathrm{ab}}$

8,11

Energy

Matéria orgânica

$44,18^{\mathrm{b}}$

$58,83^{\mathrm{a}}$

$61,01^{\mathrm{a}}$

$54,42^{\mathrm{a}}$

6,64

Proteína bruta

$50,56^{\mathrm{a}}$

$42,02^{\mathrm{b}}$

$40,29^{b}$

$42,93^{\mathrm{b}}$

7,89

Crude protein

Extrato etéreo

$78,39^{a}$

$83,17^{\mathrm{a}}$

$77,75^{\mathrm{a}}$

$70,12^{\mathrm{a}}$

9,48

Fibra detergente neutro

$40,38^{\mathrm{c}}$

$59,27^{\mathrm{ab}}$

$68,71^{\mathrm{a}}$

$52,64^{\mathrm{b}}$

11,26

Neutral detergentfiber

Extrato não-nitrogenado

$61,24^{\mathrm{a}}$

$61,15^{\mathrm{a}}$

$60,35^{\mathrm{a}}$

$62,31^{\mathrm{a}}$

5,53

$\operatorname{NDT}(\%)$

$39,99^{c}$

$53,75^{\mathrm{ab}}$

$55,88^{\mathrm{a}}$

$49,30^{\mathrm{b}}$

6,48

* Médias, na linha, seguidas por letras diferentes diferem $(\mathrm{P}<0,05)$ pelo teste Tukey.

* Means, within a row, followed by different letters differ $(P<.05)$ by Tukey test.

de piso de galpão, enquanto neste trabalho adotou-se a proporção de $10,0 \mathrm{~kg}$ de cama $/ \mathrm{m}^{2}$ de piso, o que contribuiu para as variações observadas. Utilizando-se $10,0 \mathrm{~kg}$ de maravalha/m², GARCIA et al. (1997) também obtiveram teores elevados de matéria seca $(77,85 \%)$ e FDA $(44,93 \%)$ e $13,34 \%$ de proteína bruta, enquanto JORGE et al. (1997) determi- naram 79,5\% de MS na cama de frango de maravalha produzida em camada de $7 \mathrm{~cm}$ de espessura.

A cama de frango de raspa de madeira apresentou teor elevado de lignina $13,50 \%$ na MS, entretanto, GARCIA et al. (1997), ao trabalharem com este tipo de cama de frango, obtiveram teor aproximado, $12,02 \%$. A energia bruta da cama de raspa de madei- 
ra (4046 kcal/kgMS) também se aproximou do valor $4173,14 \mathrm{kcal} / \mathrm{kgMS}$, obtido por GARCIA et al. (1997).

A DMS e DMO das camas de frango de sabugo com palha, capim-elefante e parte aérea da mandioca mostraram-se superiores $(\mathrm{P}<0,01)$ às da cama de frango de raspa de madeira.

Os resultados da DMS e DMO das camas de frango, obtidos pelo método in vivo, apresentaramse inferiores aos obtidos por SOBREIRA et al. (1997), pelo método in vitro, exceto para DMO das camas de raspa de madeira e de parte aérea da mandioca, materiais de digestibilidade mais baixa. Os resultados para DMS e DMO in vivo da cama de raspa de madeira apresentaram-se baixos, o que também foi constatado por GARCIA et al. (1997) e OLIVEIRA et al. (1991), ao avaliarem a digestibilidade in vitro da cama de frango de casca de amendoim em função do tempo de estocagem. PEREIRA (1986), ao avaliar a digestibilidade in vivo de camas de frango de sabugo de milho e de capim-elefante cameron em ovinos, obteve, respectivamente, DMS, 45,9 e 44,0\% e DMO, 49, 1 e 48,7\%, valores inferiores aos obtidos neste trabalho. Entretanto, esse autor trabalhou com cama proveniente de lote de frangos abatido aos 45 dias e criado em uma cama com $6 \mathrm{~cm}$ de altura, enquanto neste trabalho considerou-se produção por 49 dias e material absorvente na proporção de $1,0 \mathrm{~kg} /$ ave instalada.

A DFDN das camas de frango de sabugo com palha e de capim-elefante não diferiu, sendo superior $(\mathrm{P}<0,01)$ à da cama de frango de raspa de madeira. $\mathrm{A}$ cama de frango de parte aérea da mandioca apresentou DFDN superior $(\mathrm{P}<0,01)$ à da cama de raspa de madeira. As baixas DMS e DFDN nas camas de frango com elevados teores de lignina estão de acordo com afirmativa de SILVA (1981) de que o teor de lignina influi na digestibilidade destes nutrientes.

A DPB da cama de frango de raspa de madeira foi superior à dos demais tipos de cama avaliadas. A superioridade da DPB da cama de frango de raspa de madeira em relação à cama de sabugo com palha está de acordo com resultados obtidos por RODRIGUEZ (1975) para camas de frango de maravalha e de sabugo oriundas de criação de frangos por onze semanas. Os resultados obtidos por esse autor foram de 66,7 e $56,2 \%$, respectivamente. A DPB das camas de frango de sabugo com palha e de capim-elefante aproximou-se dos resultados obtidos por PEREIRA (1986), para camas de frango de sabugo e capimelefante Cameron originárias de criação por 45 dias, 45,8 e $43,8 \%$, respectivamente.
A proteína digestível na matéria seca das camas de frango de raspa de madeira, capim-elefante, sabugo com palha e parte aérea da mandioca foi, respectivamente, 5,$2 ; 4,4 ; 4,3 ;$ e 5,7\%, inferior aos resultados de RODRIGUEZ (1975) para camas de frango de maravalha $(9,42 \%)$ e de sabugo $(7,97 \%)$, e de PEREIRA (1986) para camas de frango de capimelefante Cameron $(8,00 \%)$ e de sabugo $(7,90 \%)$.

Os valores observados para DEE e DENN foram elevados, assemelhando-se aos obtidos por BHATTACHARYA e FONTENOT (1966), que trabalharam com dietas para ovinos contendo $50 \%$ de cama de frango de raspa de madeira e obtiveram, respectivamente, 62,7 e 68,8\% para DEE e DENN. MAYNARD et al. (1984) destacaram as perdas gasosas como fator determinante da elevada digestibilidade dos carboidratos. Com relação à DEE, estes valores não têm grande significado, devido ao baixo conteúdo de extrato etéreo nestes tipos de camas.

A digestibilidade da energia (DE) das camas de frango de capim-elefante e de sabugo com palha mostrou-se superior $(\mathrm{P}<0,01)$ à de raspa de madeira, não se verificando diferenças entre a cama de frango de parte aérea da mandioca e as demais. Os valores obtidos para DE das camas de frango de capimelefante e de sabugo com palha aproximaram-se da digestibilidade in vitro da cama de frango de casca de amendoim em função do tempo de estocagem, média de 50,72\%, obtida por OLIVEIRA et al. (1991).

A concentração de NDT observada para a cama de raspa de madeira foi inferior à das demais camas de frango avaliadas. Por outro lado, o maior valor obtido ocorreu para a cama de sabugo com palha, a qual não diferiu da constituída por capim-elefante, sendo que esta também não diferiu da cama de parte aérea da mandioca. Verificou-se maior teor de NDT na cama de frango de sabugo com palha em relação à de parte aérea da mandioca. O NDT das camas de frango de sabugo com palha e de capim-elefante está de acordo com dados de BUTOLO (1981), sendo que o NDT da cama de frango de raspa de madeira se mostrou inferior ao valor obtido por GARCIA et al. (1997), 44,87\%.

\section{Conclusões}

Considerando-se a digestibilidade dos nutrientes, e o valor energético com base no NDT, as camas de frango de sabugo com palha e de capim-elefante apresentaram bom valor nutritivo para alimentação de ruminantes.

A cama de frango de raspa de madeira é de baixa qualidade para alimentação de ruminantes. 
Rev. bras. zootec.

\section{Referências Bibliográficas}

ANGELO, J.C., GONZALES, E., KONDO, N. et al. 1997. Material de cama: qualidade, quantidade e efeito sobre o desempenho de frangos de corte. R. Bras. Zootec., 26(1):121-130.

AZEVEDO, A.R., ALVES, A.A., AZEVEDO JR., A.R. 1999. Digestibilidade "in vivo" da fração fibrosa de camas de frango. R. Bras. Zootec., 28(1):81-85.

BHATTACHARYA, A.N., FONTENOT, J.P. 1966. Protein and energy value of peanut hull and wood shaving poultry litters. J. Anim. Sci., 25(2):367-371.

BUTOLO, J.E. Aproveitamento de produtos não usuais na alimentação do gado leiteiro. In: SIMPÓSIO SOBRE PECUÁRIA LEITEIRA, 2, 1979, São José dos Campos. Anais... Campinas: Fundação Cargill, 1981. p.94-188.

EL-SABBAN, F.F., BRATZLER, J.W., LONG, T.A. et al. 1970. Value of processed poultry waste as a feed for ruminants. $J$. Anim. Sci., 31(1):107-111.

ENGLERT, S.I. 1998. Avicultura: tudo sobre raças, manejo, alimentação e sanidade. 7.ed. Guaíba: Agropecuária. 238p.

ENSMINGER, M. E., OLDFIELD, J. E., HEINEMANN, W. W. 1990. Feeds \& Nutrition. 2.ed. California: The Ensminger Publishing Company. 1544p.

GARCIA, C.P., AZEVEDO, A.R., ALVES, A.A. et al. 1997. Digestibilidade de camas de frango à base de materiais absorventes alternativos. R. Bras. Zootec., 26(3):524-527.

JORGE, M.A., MOUCHREK, E., CARNEIRO, M.I.F. et al. 1997. Coliformes em cinco tipos de cama de frango em reutilização. Arq. Bras. Med. Vet. Zootec., 49(5):523-550.

MAYNARD, L.A., LOOSLI, J.K., HINTZ, H.F. et al. 1984. Nutrição animal. 3. ed. Rio de Janeiro: Freitas Bastos. 736p.

OLIVEIRA, M.D.S., VIEIRA, P.F., SAMPAIO, A.A.M. et al. 1991. Digestibilidade "in vitro" da cama de frango de casca de amendoim em diferentes tempos de estocagem. Pesq. Agropec. Bras., 26(8):1161-1164.

PEREIRA, J.C. Digestibilidade de camas de frango em ovinos e caprinos. Viçosa, MG: UFV, 1986.49p. Dissertação (Mestrado em Zootecnia) - Universidade Federal de Viçosa, 1986.

POLAQUINI, L.E.M., SCHOCKEN-ITURRINO, R.P., SORBARA, J.O. et al. Estudo de toxina botulínica e esporos de Clostridium botulinum em amostras de cama de frango, coletadas em aviários. In: REUNIÃO ANUAL DA SOCIEDADE BRSILEIRA DE ZOOTECNIA, 34, 1997, Juiz de Fora. Anais... Juiz de Fora: SBZ, 1997. p.449-450.
RODRIGUEZ, H.A.G. Digestibilidade em carneiros de diferentes tipos de cama de frango. Viçosa, MG: UFV, 1975. 43p. Tese (Mestrado em Zootecnia) - Universidade Federal de Viçosa, 1975.

SAMPAIO, A.A.M., EZEQUIEL, J.M.B., CAMPOS, F.P. et al. 1995. Utilização da cama de frango e da soja-grão na alimentação de bovinos confinados. R. Soc. Bras. Zootec., 24(2):252-260.

SCHOCKEN-ITURRINO, R.P., FREITAS, J.C.M., SAMPAIO, A.A.M. et al. 1992. Laying hen feces for ruminant feeds: microbiological analysis. Pesq. Agropec. Bras., 27(10):1439-1442.

SILVA, D.J. 1981. Análise de Alimentos: Métodos Químicos e Biológicos. Viçosa: UFV. 166p.

SNEDECOR, G.W., COCHRAN, W.G. 1980. Statisticalmethods. 7.ed. Iowa: The Iowa State University Press, 507p.

SOBREIRA, A.L.M.A., AZEVEDO, A.R., ALVES, A.A. et al. Avaliação da fração fibrosa e da digestibilidade "in vitro" de diferentes tipos de cama de frango, em função do tempo de estocagem. In: REUNIÃO ANUAL DA SOCIEDADE BRSILEIRA DE ZOOTECNIA, 33, 1996, Fortaleza. Anais... Fortaleza: SBZ, 1996. p.458-459.

SOBREIRA, A.L.M.A., AZEVEDO, A.R., ALVES, A.A. et al. Digestibilidade "in vitro" da matéria seca e da matéria orgânica de diferentes tipos de cama de frango. In: REUNIÃO ANUAL DA SOCIEDADE BRASILEIRA DE ZOOTECNIA, 34, 1997, Juiz de Fora. Anais... Juiz de Fora: SBZ, 1997. p.73-75.

Recebido em: 21/05/97

Aceito em: 08/03/99 